\title{
Evaluating the economic impact of a preventative seismic legislation in Ecuador
}

\author{
Juan Ponce \\ Director of Flacso-Ecuador. \\ Andrés Salazar \\ Master student from Flacso-Ecuador.
}

\begin{abstract}
At the end of 2013 a compulsory inspection policy was introduced in Quito-Ecuador to ensure that new buildings complied with seismic resistant design requirements. This policy could affect the economic sector of construction by increasing the cost of buildings. It is in this context that this paper analyses the economic impact of the new construction policy. Given that this policy only applied to the canton of Quito and not to any other canton in Ecuador, the paper creates a synthetic control group on the basis of infrastructure and socio-economic data of the fifteen most heavily populated cantons in the country. The results show a statistically significant and negative impact. In other words, although the new policy succeeded in improving the seismic resistant quality of buildings in the canton of Quito, at the same time it had a negative effect on the per capita gross value added of the construction sector.
\end{abstract}

Keywords: Prevention, Seismic policy, Synthetic control group, Ecuador, Impact evaluation Subject classification codes: JEL: C01, C14, C23, H83

\section{INTRODUCTION}

Earthquakes can change the course of a country overnight, result in the deaths of thousands of people, devastate its infrastructure and do lasting damage to its economy (Kalantari 2012). There is no doubt that all countries that lie in high-risk earthquake regions need to have housing policies that minimize the seismic vulnerability of their infrastructure (Cardona et al. 2008). Unfortunately, in some countries it regularly happens that insufficient funds are invested in prevention policies and all their efforts and resources are concentrated on the time after the earthquake has struck.

As is well-known natural disasters affect the population of the country in different ways, depending on their social conditions (Lafuente, Grases and Genatios 2014). The most socially and economically vulnerable groups are most affected by the consequences of natural disasters. One of the causes of this is precisely because poor residents tend to settle in informal townships and areas of danger.

In addition to socio-economic conditions, institutional designs are also important. The effects of natural disasters can be greater in areas with shortcomings in their institutional framework, with weaknesses in their regulation and control mechanisms, with inadequacies in their territorial and urban planning and with a lack of adequate policies for the reduction of risks from disasters (Lafuente, Grases and Genatios 2014).

In this sense the management of disaster risks constitutes an important area of public policy. A change from a focus based on responding to emergencies is currently being promoted in favour 
of a focus with an emphasis on prevention in order to reduce the consequences of such phenomena (CEPAL 2007). On this basis some core prevention policies have been established by legislation, such as the division into seismic risk zones and the constant updating of construction regulations and quality control of buildings. The division into seismic risk zones makes it possible to establish the belts of greatest seismic danger, plus the vulnerability of different areas. The updating of construction regulations establishes compulsory directives in the design of construction projects, including the best technological advances in the matter of seismic resistant structural design. Finally, the quality control of building refers to the inspection of standards, materials and technical specifications used in building construction.

In most developing countries quality control is applied when buildings have already been finished; once the buildings have been constructed they are checked to see that they correspond to the specifications in the original design. The problem is that no-one carefully checks the content of the original design, also known as seismic design or seismic resistant design of the construction.

In the case of Ecuador, as in other developing countries, there is a stage in the quality control construction process in the vast majority of cantons that is not rigorously applied. The seismic resistant design of the building is not examined or inspected in depth by any institution. The seismic resistant design refers to the documents that contain all the information necessary for the construction of the project, specifying all the measurement details and the types of material to be used. Exceptionally, at the end of 2013 a process of compulsory inspection of the seismic resistant design of construction was implemented in the canton of Quito.

In economic terms it is appropriate to note the importance of infrastructure for a country's economic growth (Esfahani and Ramirez 2003), as well as the importance of the quality of the infrastructure and its deterioration (Duffy-Deno and Eberts 1991). Within the country itself the regions with more and better infrastructure have better economic growth (Démurger 2001). Earthquakes can do serious damage to the infrastructure if there is no suitable prevention policy.

By way of example the earthquakes in Managua in 1972, Mexico in 1985 and Nicaragua in 1992 had considerable effects on the economy: a reduction in GDP, a loss of revenue, fiscal deficit, deficit on the current account balance of payments and damage to the infrastructure (Calderón 2012).

Countries such as Japan and Chile, which are well-known for dealing with major earthquakes, have made the greatest advances in terms of quality control of seismic design in buildings (Leyton, Ruiz and Sepúlveda 2010), whereas in other countries - for example in Haiti - there is no regulation. This explains why around 500 people died in Chile on account of the earthquake in 2010 (Bárcena et al 2010), whereas in Haiti, in the earthquake of the same year more than 200,000 people died (Cavaletto 2012). While the Chilean earthquake measured $8.8 \mathrm{Mw}$, the one in Haiti was lower at 7.0 Mw.

One of the key components in Chile is the compulsory and independent review of every seismic design for construction projects throughout the country (Saragoni 2011). Consequently, in spite of being one of the most earthquake-prone countries in the world, it is also a model of seismic safety (Cisternas 2011). In the case of Japan, the production of engineering designs also has to have the approval of construction specialists (Murota 1995). In other countries like New Zealand they have also introduced new regulations for the granting of licences for professionals who carry out structural design (Hopkins et al 2008). 
As far as we are aware there are no studies in the literature that analyse the economic effect that could be caused by the implementation of regulation standards and seismic safety control in buildings. The contribution of our study is to analyse for the first time the economic effect of the application of this type of regulation within the framework of a broader public policy of prevention.

The study is organised as follows: in the next section the context of the country and a description of the regulation and control policy is presented. This is followed by the database and the identification strategy used. The next section presents the results, followed by a discussion of the results and finally the conclusions.

\section{CONTEXT OF THE COUNTRY AND ANALYSIS OF POLICY}

Ecuador is a country with high levels of inequality and poverty (Ponce and Bedi 2009). With around 16 million inhabitants, Ecuador's GDP in 2016 was US\$ 98 billion (BCE 2016). At the end of 2016 the Gini coefficient was 0.466 at the national level (INEC 2016), while the incidence of poverty and extreme poverty at national level stood at $22.9 \%$ and $8.7 \%$ respectively (INEC 2016). This situation is more extreme in rural areas where the incidence of poverty and extreme poverty are $38.2 \%$ and $17.6 \%$ respectively.

In geographical terms Ecuador is situated in the so-called Pacific ring of fire, a region classified as one of the greatest seismic threat in the world (Lafuente, Grases and Genatios 2014). In 2016 the country suffered an earthquake of $7.8 \mathrm{Mw}$, affecting the provinces of Manabí and Esmeraldas. The damage included loss of life and infrastructure that hit the economy as a whole. There was a total of 663 dead and 80,000 people displaced. Around 30,000 buildings and 83 kilometres of roads were affected (INEC 2017). From the macroeconomic perspective it is estimated that about 22,000 jobs were lost with a reduction in the GDP of 0.7 percentage points (INEC 2017). The total cost of reconstruction (which included repairs to roads, schools and health centres, as well as productive incentives and monetary transfers to the most vulnerable people) reached around 3 billion dollars (INEC 2017).

In general terms, at the moment of the earthquake Ecuador was in a highly vulnerable state with regard to its buildings and unprepared in relation to prevention policies. A notable exception is the city of Quito, the state capital, where in October 2013 a municipal resolution was issued (Quito Metropolitan Council 2013) which includes an additional compulsory requirement in order to obtain a construction licence. The structural engineering design of every private sector construction project has to be examined by an institution that certifies whether the project in question meets the regulatory construction standards in the country, with particular emphasis on the seismic design aspects. The examining institution, called the Collaborating Body for Project (Entidad Colaboradora de Proyectos), has the power to approve or refuse construction projects. Thereafter the certificate of approval awarded by the group of examining civil engineers from the Collaborating Body for Projects became an indispensable requirement in the canton of Quito before the corresponding construction licence could be obtained, which compelled all building developers to go through this inspection process as a conditional requirement.

This compulsory inspection of the structural design meant a sudden reduction in the number of construction permits issued in Quito (INEC 2014), as can be seen in Figure 1. 
Figure I. Construction permits issued in the canton of Quito

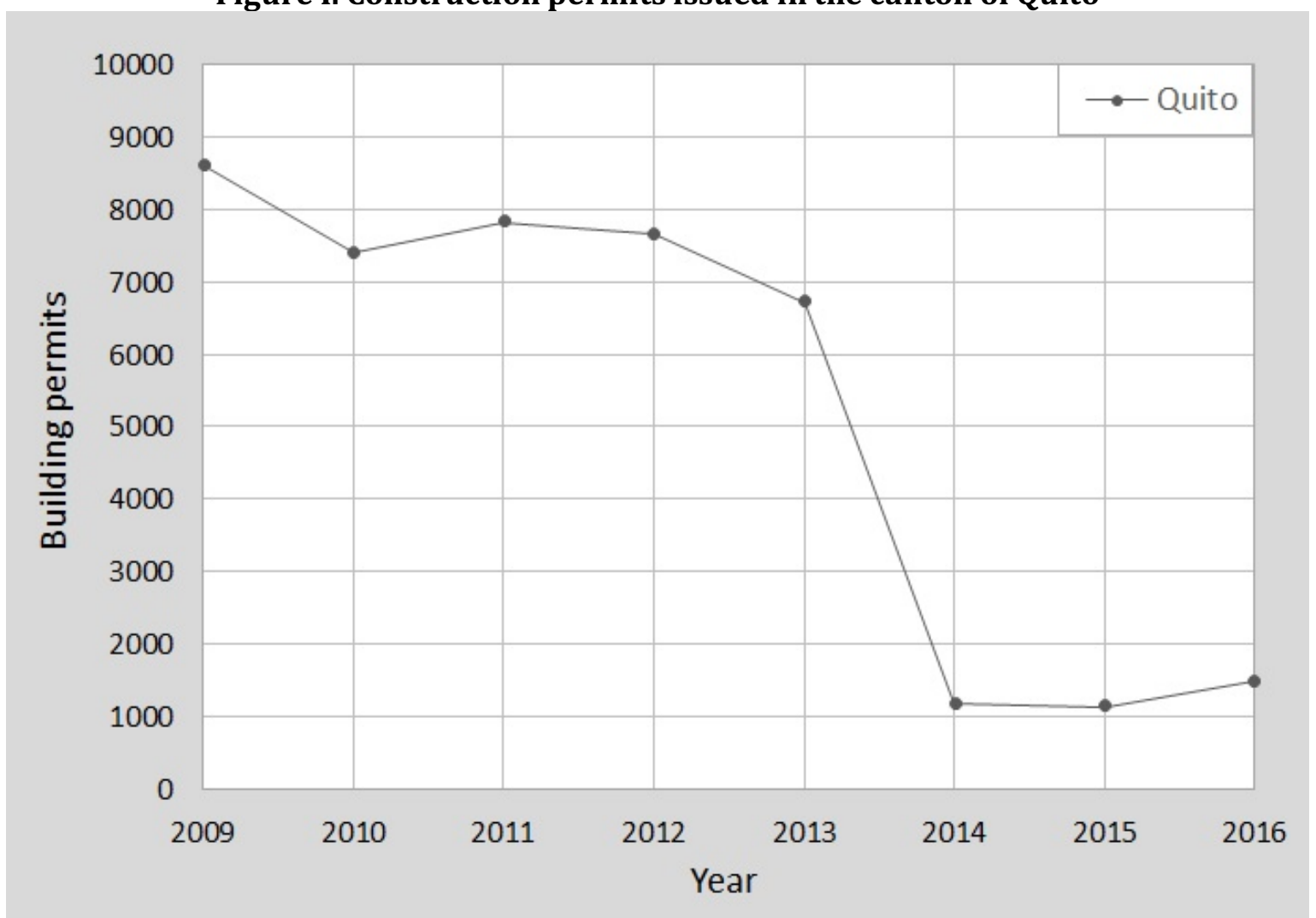

At national level the intention was to improve the construction regulation system with the issue of the Ecuadorean Construction Standard (Norma Ecuatoriana de la Construcción) 2011, known as NEC-11. This standard established high levels of seismic specifications and when it came into operation the construction sector did not cope with it for very long, since the cost of buildings went up considerably. In the face of this pressure, a few months later the standard was replaced by one with somewhat less stringent requirements, the NEC-15.

From the technical perspective of seismic design, a more demanding standard is inevitably going to mean higher safety levels for buildings. In the face of this there are two options: the first clearly concerns engineering and consists of finding more efficient structural configurations, in other words, a greater seismic response capability is achieved with the same or smaller quantity of materials. This is definitely the more desirable alternative, since it would be very beneficial in economic terms and in its potential large-scale application for people. But this alternative depends at the moment on scientific advances in the field. The second alternative is plainly economic and needs an understanding of the extent to which it is appropriate to raise the requirements of seismic safety, without the costs of structures rising so high that it becomes unavailable for a large sector of the population. This solution produces the dilemma of building safer houses for fewer people or building less safe houses for more people. Obviously we should be aiming at striking a balance in which safer houses for more people can be built.

\section{DATA AND METHODOLOGY}

The database was constructed using two main sources: the Canton Accounts of the Ecuador Central Bank (BCE) and the Annual Buildings Survey carried out by the National Institute of Statistics and Census (INEC). The following variables were obtained from the first of these: the gross value added (VAB) of the construction sector, national production and the secondary component of the VAB in professional and property activities. The following variables were obtained from the second source: construction licences, the number of dwellings per building, 
the number of bedrooms. Finally, the following variables were obtained from other INEC sources: total number of live births, number of marriages and population projections. Table I shows the averages and variances of the database variables.

Table I - Averages and variances of the variables used in the study

\begin{tabular}{|l|c|c|}
\hline Variable & Mean & Variance \\
\hline Population (national) & 15182545 & $1.1110 \mathrm{E}+12$ \\
\hline Production per capita (national) & 8.9132 & 1.9713 \\
\hline Gross value added per capita, construction sector (national) & 0.5396 & 0.0214 \\
\hline $\begin{array}{l}\text { Gross value added per capita, professional and property sector } \\
\text { (national) }\end{array}$ & 0.5979 & 0.0088 \\
\hline Number of construction licences per capita (national) & 0.0023 & $1.7944 \mathrm{E}-07$ \\
\hline Number of dwellings per capita (national) & 0.0046 & $1.0618 \mathrm{E}-06$ \\
\hline Number of bedrooms per capita (national) & 0.0129 & $4.7065 \mathrm{E}-06$ \\
\hline Number of live births per capita (national) & 0.0205 & $7.3235 \mathrm{E}-06$ \\
\hline Number of marriages per capita (national) & 0.0045 & $8.3179 \mathrm{E}-07$ \\
\hline
\end{tabular}

Given that the policy only applied to the canton of Quito it was decided to use, as an identification strategy, the synthetic control method developed by Abadie and colleagues (Abadie, Diamond and Hainmueller 2010, 2011). The basis of this method consists of contrasting the trajectory of the treated unit (Quito) with the counterfactual trajectory formed by the combination of several control units (other cantons). The cantons taking part in the formation of the synthetic control group are chosen through the development of the mathematical methodology provided by Abadie and colleagues (Abadie, Diamond and Hainmueller 2011) and complemented by Galiani (Galiani and Quistorff 2017).

The synthetic control method requires data before and after the intervention, both for the treatment unit and for the units that serve to make up the synthetic control (donor pool). An econometric model is used to predict the result variable based on explicative variables. Optimal weightings were assigned both to the variables and to the units in such a way that the synthetic control succeeds in replicating the trajectory of the treatment unit. Therefore, the synthetic control is made up of a weighted average of the units not subject to the intervention. The key assumption of the method is to get the synthetic control to replicate the trajectory of the treatment unit in the period prior to the intervention. In this way the counterfactual scenario, which tells us what would have happened if the intervention had not occurred, is provided by the trajectory of the synthetic control group in the period following the intervention. Thus the impact is calculated by the trajectory difference between the synthetic group and the treatment group in the period following the intervention.

\section{RESULTS}

As already indicated the identification strategy used is ideal for the present study since the only canton in Ecuador to adopt the policy of the compulsory inspection of plans was Quito. This is therefore our treatment unit. As donor pool (on the basis of which the synthetic control unit was to be formed) the 14 cantons with the largest population in the country in 2013 were chosen. These cantons offer an important dynamic in the construction sector and a full history of construction data since 2007. The year 2014 is taken as the intervention year (since the standard was approved in October 2013). The result variable is confirmed as the sector component of the gross value added (VAB) in construction (the macroeconomic variable), quite an appropriate indicator to measure the economic effect of the policy in operation since it focuses specifically on the construction sector at the level of the canton. The following were 
used as the predictor variables: total production (cantonal macroeconomic variable), sector component of the VAB in professional activities and property (cantonal macroeconomic variable), construction licences, number of dwellings per building, estimated number of bedrooms, number of live births and number of marriages.

In the first place the following chart shows the evolution of the treatment unit and the synthetic control unit in the result variable (VAB of construction).

Figure II. Evolution of the construction VAB for Quito and for the synthetic control

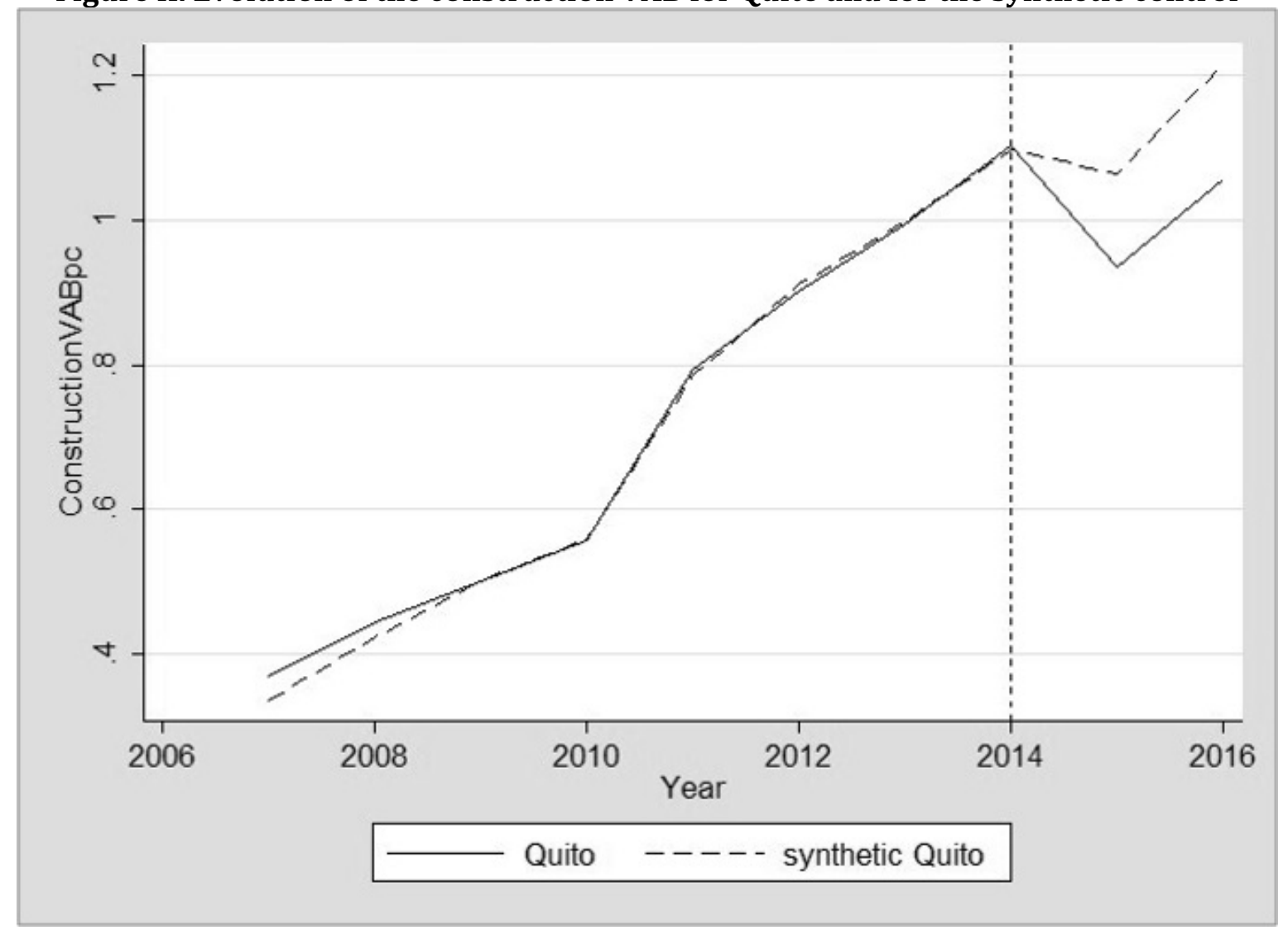

As can be seen the synthetic control group succeeds in replicating the Quito trajectory in the period prior to the intervention. Until 2014 the two lines overlapped. This is the basic theory of the validity of the identification strategy used. From 2014 onwards there is a difference between the two trajectories, which is due to the effect of the policy applied in Quito. A reduction can be seen in the per capita gross value added in construction in Quito in the years 2015 and 2016.

As indicated earlier the synthetic control group consists of the 14 cantons with the highest population, with the percentage weightings indicated in Table II. 
Table II: Weights of the control units to make up the synthetic group

\begin{tabular}{|l|l|}
\hline Canton & Unit Weight \\
\hline Cuenca & 0.278 \\
\hline Latacunga & 0 \\
\hline Riobamba & 0 \\
\hline Machala & 0 \\
\hline Esmeraldas & 0 \\
\hline Guayaquil & 0.32 \\
\hline Durán & 0 \\
\hline Ibarra & 0 \\
\hline Loja & 0 \\
\hline Quevedo & 0 \\
\hline Portoviejo & 0.147 \\
\hline Manta & 0 \\
\hline Ambato & 0.255 \\
\hline Santo Domingo & 0 \\
\hline
\end{tabular}

The cantons with the highest weighting in the configuration of the synthetic control are: Guayaquil, Cuenca, Ambato and Portoviejo. The remaining cantons have a zero weighting.

Another way of considering in a formal manner whether the synthetic control group is properly reproducing the behaviour of the treatment group before the intervention is by comparing the values of the predictor variables between the two groups. The results are shown in Table III.

Table III - Unit values of treated versus synthetic group

\begin{tabular}{|l|c|c|}
\hline Predictor Variables (per capita) & Treated & Synthetic \\
\hline Building licences & 0.0026944 & 0.0033558 \\
\hline Number of bedrooms & 0.0223452 & 0.022378 \\
\hline Production & 12.42503 & 8.912184 \\
\hline VAB in professional activities and property & 1.553306 & 0.6870604 \\
\hline Number of dwellings & 0.008703 & 0.008051 \\
\hline Number of marriages & 0.0060525 & 0.0057434 \\
\hline Number of live births & 0.020195 & 0.0215321 \\
\hline
\end{tabular}

As can be seen, all of the values in the table are very similar between the treatment group and the synthetic control group. This is also reflected in the appropriate reproduction of the trajectory of the treatment group on the part of the synthetic control in the period prior to the intervention, as was shown in Figure 1.

\section{INFERENCE}

According to the methodology used, placebo tests have been carried out in order to consider the statistical significance of the estimators. In order to do this, synthetic control groups were formed resulting from iterations in which each one of the 14 cantons is considered as the treated unit, while the Quito canton together with the others goes to form part of the 14 cantons that make up the control group. Using this procedure, the standardized p-values of the 
estimators can be obtained in order to see their statistical significance (Galiani and Quistorff 2017).

The following table shows the impact coefficient and the standardized p-value.

Table IV. Coefficient and p-value of the impact

\begin{tabular}{|c|c|c|}
\hline Year & $\begin{array}{c}\text { Impact on VAB per capita } \\
\text { of construction }\end{array}$ & $\begin{array}{c}\text { Standardized } \\
\text { p-value }\end{array}$ \\
\hline 2014 & 0,0055045 & 0,8461538 \\
\hline 2015 & $-0,1300665$ & 0,0769231 \\
\hline 2016 & $-0,1593213$ & 0,0769231 \\
\hline
\end{tabular}

As was seen in the previous table, there is a negative effect (significant at $90 \%$ ) in the years 2015 and 2016. The reduction in the per capita gross value added in construction in Quito, in the years 2015 and 2016, was US\$ 130 and US\$ 159 dollars per capita respectively.

\section{DISCUSSION}

An important aspect to consider in the present study is that from 2010 onwards the Bank of the Ecuadorean Institute of Social Security (BIESS) provided a large number of mortgage loans to cover housing costs. The loans granted could be used for the following items: new dwelling, dwelling construction, refurbishment and extensions, mortgage replacement, land and construction, other property and mortgaged dwelling (BIESS 2018). For the present study, the following three categories of loans are of particular interest: dwelling construction, refurbishment and extensions, land and construction. These categories of loans involve the management of construction permits for new build projects. The mortgage loans began to be restricted on account of BIESS liquidity problems. To the extent that there is a large number of branches of the IESS in Quito, especially in greater proportion than in other cantons, this restriction may affect the results found earlier.

Figure III. BIESS National Mortgage loans - net transferred value (US\$ millions)

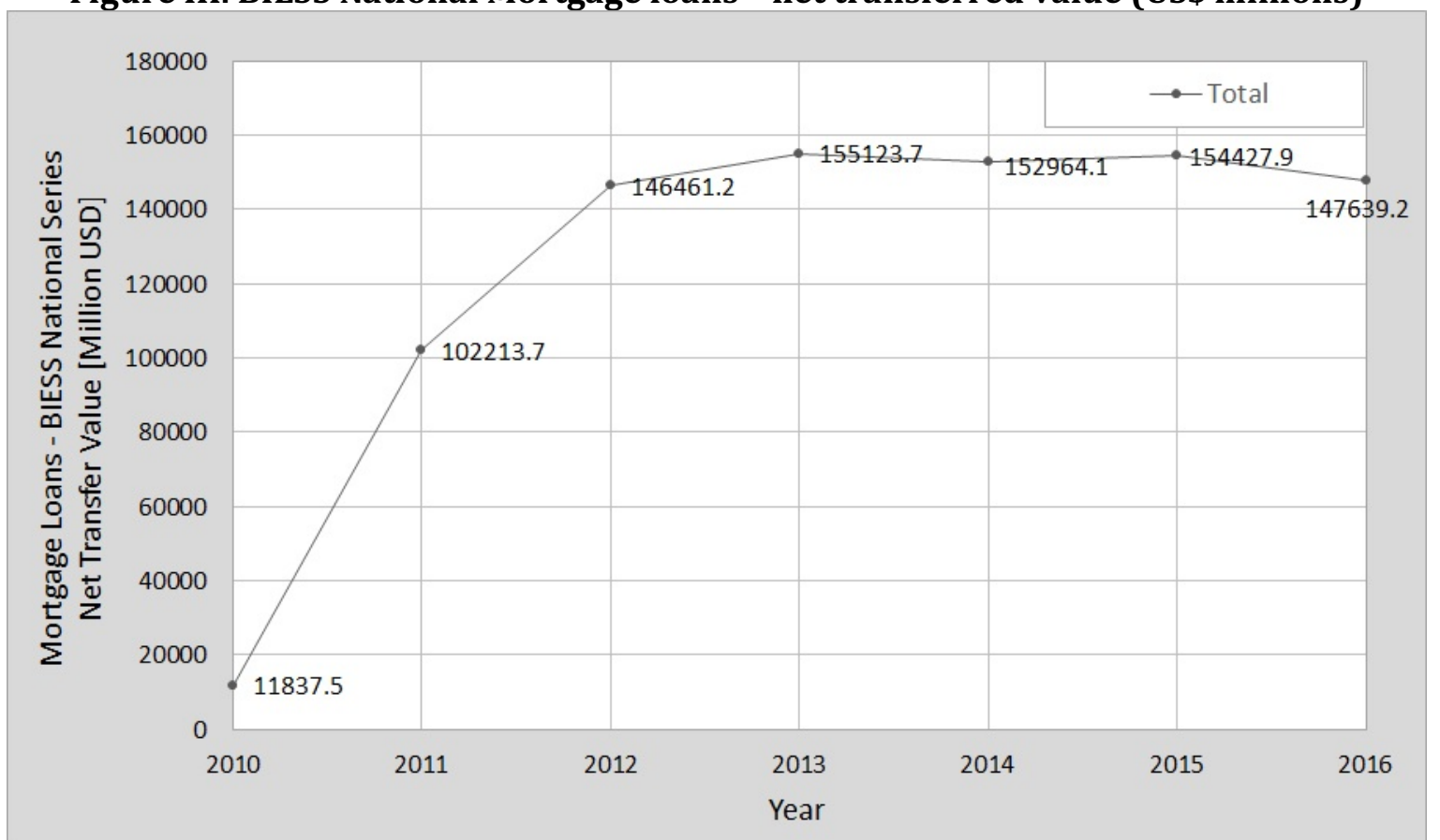

Note: Sum of categories considered: dwelling construction, refurbishment and extensions, land and construction 
As mentioned previously, the intervention of 2014 (the policy of the compulsory inspection of structural plans) produced a direct decrease in construction licenses in the canton of Quito and a statistically significant impact on the reduction of the construction component of the per capita gross value added. From figure 3 we can conclude that these effects are not related to the trajectory of the mortgage loans granted by the BIESS. The total of BIESS loans remained stable between 2013 and 2016. Therefore, we can conclude that there is no consistent correlation between the upward or downward trends of the performance trajectories of the variables indicated and the mortgage loans granted by the BIESS.

Another variable relevant for the present study is the price of the square meter of construction. We had access to price information only for Quito and Guayaquil (the most important canton among the donor pool). Figure 4 shows the evolution of the price of square meter of construction. As we can see, both lines maintain exactly the same trend form 2012 onwards. The previous means that the policy evaluated apparently is not related to changes in the price of the square meter of construction.

Figure IV. Value per square meter of construction (US\$ $/ \mathrm{m}^{2}$ )

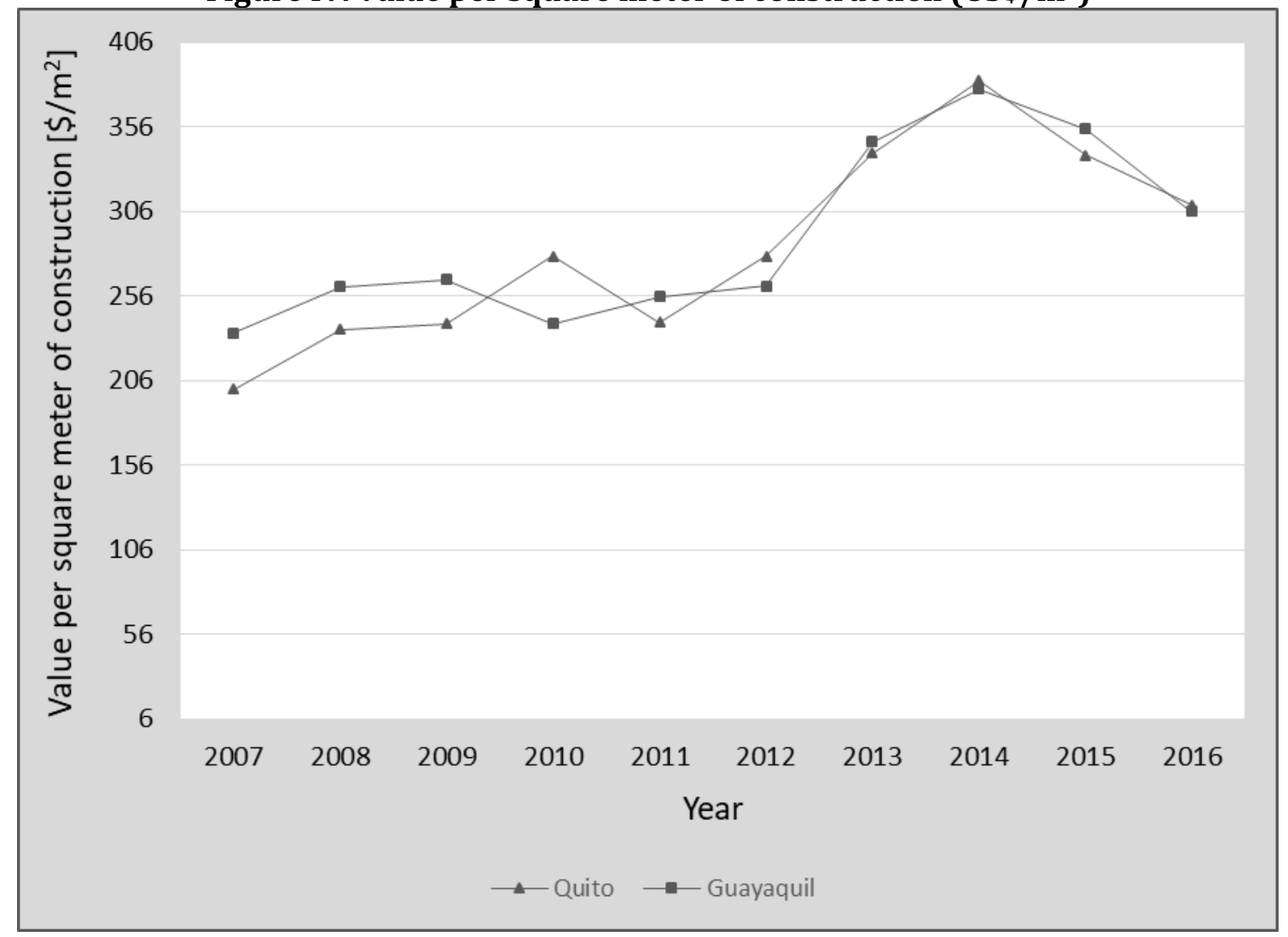

Source: INEC 2007-2016. Buildings survey.

Note: Data obtained from the division between total value of the calculated building CVAE and total construction surface CARCO

\section{CONCLUSIONS}

Faced with the underlying need to strengthen preventative seismic legislation in Ecuador, the policy of compulsory inspection of seismic-resistant designs in Quito represents a significant improvement in the building quality and a substantial contribution towards the reduction in the seismic vulnerability of the region's infrastructure. At the same time, it has to be accepted that the measure in question had a negative effect on the construction sector since it caused a reduction in the construction component of the gross value added per capita. Specifically, the intervention produced a statistically significant impact in the years 2015 and 2016, with a 
confidence interval of $90 \%$. The reduction in the per capita gross value added in construction in Quito, in the years 2015 and 2016, was US\$ 130 and US\$ 159 dollars per capita respectively. The aspects analysed are important elements for those responsible for public housing policy where the requirements of seismic regulations need to be implemented. The conclusion is that the impact on the construction sector would not be so strong and could recover in the shortest possible time.

A similar policy of compulsory inspection should be implemented in more cantons in Ecuador, with the objective of strengthening processes of a preventative nature and significantly reducing the vulnerability of constructions to seismic threats. The compulsory inspection policy would preferably have a minor effect on the construction sector in its initial application, but in the long term it should improve the quality of the infrastructure and strengthen the construction sector by making it part of the processes that represent greater reliability for investors and consumers.

With regard to the question of regulatory updating, it is important to take into account the scale of the increase that the new regulatory requirements should present compared to the previous ones. A good reference point for this is the dynamic regulations of the present case study. In this sense the period of time set for the implementation of compulsory improvements in seismic regulations should be considered on the basis of offering sufficient time to the economic sector of construction for it to adapt and recover.

It is essential to strengthen the seismic legislation of a preventative nature. In addition, it is important to complement the information obtained from INEC's annual buildings survey with information that relates to the post-construction situation, in other words, there should be a detailed gathering of information regarding the quality of completed infrastructure that reflects the fundamental elements of the building process in general.

\section{References}

Abadie, Alberto, Alexis Diamond, and Jens Hainmueller. 2010. "Synthetic Control Methods for Comparative Case Studies: Estimating the Effect of California's Tobacco Control Program." Journal of the American Statistical Association 105 (490): 493-505. https://doi.org/10.1198/jasa.2009.ap08746.

——_. 2011. "Synth: An R Package for Synthetic Control Methods in Comparative Case Studies." Journal of Statistical Software 42 (13): 1-17. https://doi.org/10.18637/jss.v042.i13.

___ 2012. “Comparative Politics and the Synthetic Control Method." SSRN Electronic Journal 105 (490): 495510. https://doi.org/10.2139/ssrn.1950298.

Banco Central del Ecuador, Cuentas Cantonales (anuales)

https://www.bce.fin.ec/index.php/component/k2/item/293-cuentas-provinciales

Banco Central del Ecuador, Cuentas Nacionales Anuales

https://www.bce.fin.ec/index.php/component/k2/item/763-cuentas-nacionales

Banco del Instituto Ecuatoriano de Seguridad Social BIESS. "Reporte Estadístico". 2010-2018

https://www.biess.fin.ec/files/ley-transaparencia/reporte-estadistico/2018-09REPORTE\%20ESTAD\%C3\%8DSTICO.pdf

Banco del Instituto Ecuatoriano de Seguridad Social BIESS. "Biess en Cifras". Octubre 2010-Junio 2016

Bárcena, Alicia, Antonio Prado, Laura López, and Jose Luis Samaniego. 2010. "Terremoto En Chile - Una Primera Mirada." ECLAC Working Paper, 61.

Calderón, Cuauhtémoc, and Letizia Hernández. 2012. “El terremoto de 1985 en México y sus efectos económicos”. Cultura Científica y Tecnológica Culcyt. Desastres y Economía. N48:24-33.

Cardona, Omar D., Mario G. Ordaz, Mabel C. Marulanda, and Alex H. Barbat. 2008. "Estimation of Probabilistic Seismic Losses and the Public Economic Resilience - An Approach for a Macroeconomic Impact Evaluation." Journal of Earthquake Engineering 12 (SUPPL. 2): 60-70. https://doi.org/10.1080/13632460802013511. 
Cavaletto, Gilles. 2012. "El Terremoto de Haití 2010: Una Evaluación de La Respuesta Humanitaria. Coordinación, Financiamiento y Reconstrucción," 288. http://www.tesis.uchile.cl/handle/2250/113054.

CEPAL. 2007. "Información para la gestión de riesgo de desastres. Estudios de caso de cinco países" Informe resumido. Repositorio Comisión Económica para América Latina y el Caribe (CEPAL). https://repositorio.cepal.org/bitstream/handle/11362/25846/2/LCmexL806spa_es.pdf

CEPAL. 2001. "Vivienda y pobreza: la experiencia salvadoreña en construcción urgente tras los terremotos". Comisión Económica para América Latina y el Caribe (CEPAL). https://repositorio.cepal.org/handle/11362/25525

Cisternas, Armando. 2011. "El País Más Sísmico Del Mundo." Revista Anales de La Universidad de Chile Septima Se. https://doi.org/10.1073/pnas.0703993104.

Concejo Metropolitano de Quito, Ordenanza Metropolitana No. 433, 20 de Septiembre 2013, Disponible en: http://www7.quito.gob.ec/mdmq_ordenanzas/Ordenanzas/ORDENANZAS\%20MUNICIPALES\%202013/ORDM\% 200433\%20-\%20REFORMA\%200RD.\%20156\%20\%20REGIMEN\%20ADMINISTRATIVO\%20DEL\%20SUELO\%20\%20LICENCIAS\%20METROPOLITANAS\%20URBANISTICAS.pdf

Démurger, Sylvie. 2001. "Infrastructure Development and Economic Growth: An Explanation for Regional Disparities in China?" Journal of Comparative Economics 29 (1): 95-117. https://doi.org/10.1006/jcec.2000.1693.

Duffy-Deno, Kevin T., and Randall W. Eberts. 1991. "Public Infrastructure and Regional Economic Development: A Simultaneous Equations Approach." Journal of Urban Economics 30 (3): 329-43. https://doi.org/10.1016/00941190(91)90053-A.

Esfahani, Hadi Salehi, and Maŕa Teresa Ramírez. 2003. "Institutions, Infrastructure, and Economic Growth." Journal of Development Economics 70 (2): 443-77. https://doi.org/10.1016/S0304-3878(02)00105-0.

Galiani, Sebastian, and Brian Quistorff. 2017. "The Synth_ Runner Package: Utilities to Automate Synthetic Control Estimation Using Synth." Stata Journal 17 (4): 834-49. http://econweb.umd.edu/ galiani/files/synth_runner.pdf.

Hopkins, David C, Mike Stannard, Graeme Lawrance, and Ian Brewer. 2008. "Strengthening Buildings for Earthquake Implementing New Zealand Legislation." 14th World Conference on Earthquake Engineering.

INEC. (2007-2016). Anuarios de estadísticas de edificaciones 2007-2016 Inec. Retrieved from www.ecuadorencifras.gob.ec

INEC. 2017. "Reconstruyendo Las Cifras Luego Del Sismo" 1: 228.

http://www.ecuadorencifras.gob.ec/documentos/web-inec/Bibliotecas/Libros/Memorias 13 abr 2017.pdf.

INEC. 2016. "Reporte de pobreza y desigualdad". http://www.ecuadorencifras.gob.ec/documentos/webinec/POBREZA/2016/Diciembre_2016/Reporte\%20pobreza\%20y\%20desigualdad-dic16.pdf

INEC. 2014. "Anuario de Estadísticas de Edificaciones 2014." Inec. www.ecuadorencifras.gob.ec.

Kalantari, Afshin. 2012. "Seismic Risk of Structures and the Economic Issues of Earthquakes." InTech 1: 3,4. https://doi.org/http://dx.doi.org/10.5772/50789.

Lafuente, M., Grases, J., \& Genatios, C. (2014). Revisión de la normativa sísmica en América Latina. Geopolis;, Caracas: CAF. Retrieved from http://scioteca.caf.com/handle/123456789/897

Leyton, Felipe, Sergio Ruiz, and Sergio A. Sepúlveda. 2010. "Reevaluación de Peligro Sísmico Pobabilistico En Chile Central." Andean Geology.

Murota Tatsuo. (1995). Concepto de la regulación del diseño sísmico de construcciones en Japón. Centro Nacional de Prevención de Desastres (CENAPRED). http://www.eird.org/cd/building-

codes/pdf/spa/doc6526/doc6526.htm

Norma Ecuatoriana de la Construcción NEC 2015. CAMICON, and MIDUVI. 2014. Norma Ecuatoriana de La Construcción - NEC: NEC-SE-DS - Peligro Sísmico/Diseño Sismo Resistente. https://doi.org/10.4067/S071769962013000200001.

Ponce, Juan, and Arjun S Bedi. 2009. “The Bono de Desarrollo Humano of Ecuador.” Economics of Education Review. https://doi.org/10.1016/j.econedurev.2009.07.005.

Saragoni, Rodolfo. 2011. "El Mega Terremoto Del Maule de 2010: Una Lección de Buena Ingeniería, Pero Con Sorpresas y Nuevos Desafíos." Anales de La Universidad de Chile 0 (1): 35-56. 